\title{
Cell Surface Antigen
}

National Cancer Institute

\section{Source}

National Cancer Institute. Cell Surface Antigen. NCI Thesaurus. Code C269.

An antigenic molecule that is bound to the outer surface of a cell. 